UDC: $378+37.091 .33+811.111$

Olha Trubitsyna,

PhD (Candidate of Pedagogical Sciences), associate professor, Department of Germanic Philology and Methods of Teaching Foreign Languages,

Anna Muimaster,

Master-degree student, Faculty of Foreign Languages, South Ukrainian National Pedagogical University named after K. D. Ushynsky, 34, Staroportofrankivska Str., Odesa, Ukraine

\title{
PROJECT-BASED METHOD AS A MEANS OF INTERACTIVE TEACHING OF ENGLISH
}

The article deals with the project-based method in teaching English as a foreign language in universities. Both theoretical background and practical implementation of the method are considered in the research. The origin, main concept and the advantages of the projects-based method are described.

Keywords:project-based method, project-based teaching, higher educational institution.

The issue of modern technologies application in teaching is becoming increasingly importantdue to attracting attention to not only methods, but also to new forms and approaches. Modern education is aimed at helping the students feel confidenton the labour market, teaching them to adjust to social changes and possible crises, developing their self-organisation.Itrequires new forms of teaching and educational processes thatwill make it possible to:

1) provide a high level of knowledge and competence, ability to find information and use it;

2) develop each student as a creative personality capable ofpractical work;

3 ) engage students in active learning activity;

4) form learning and investigatory skillsand critical thinking;

5) facilitate the establishing of good relations between the students;

6) teach information search and its rational use.

One of the contemporary effective methods of teaching English isthe project-based one, which can be called "Learning by Doing" according to its origin. The method has been developed on the basis of Pragmatism (philosophical movement that appeared in the middle of the $19^{\text {th }}$ century) that implies action and practical application of knowledge in everyday life. Major proponentsof Pragmatism are J. Dewey, W. Kilpatrick, H.Gaudi [3].

Being the subject matter of the recent investigations as exemplified by its use at the lessons of mostly primary or secondary schools, the project-based method mainly has not found application in university teaching. Thus, the aim of our research is to examine the key points and the practical side of the project-based teaching of the universitystudents.

Method of projects always implies the students' independent work (individual research, pair or group work) providing the planned productive benefitand neglecting authoritative and reproductive techniques.Still, the project-based method does not contradict the traditional ways of learning. It helps activate students, since most of them are interestedin acquiring new knowledge necessary for their profession. The main purpose of this innovative ap- proach use is the opportunity for studentsto master foreign communicative competence. It includes the following concepts:

- verbal competence is creating an opportunity todemonstrateone's communicative skills in all forms: listening, speaking, writing, reading, translation within a specific topic;

socio-cultural competence is the formation of ideas about the social and cultural specificity of the target language;

- linguistic competence is students' acquisition of lexical units relating to the topic as a necessary basis for speaking abilities registration [3].

Simon Haines (a famous British college teacher, an author of numerous works on teaching English as a foreign language) identifies four types of projects:

1. Information and research projects that include such kinds of work as reports, displays.

2. Survey projects that include interviews, summaries, findings, etc.

3. Production projects that imply work with radio, television, video, newspapers.

4. Organisational projects (or performance projects) that are connected with parties, plays, drama, concerts, public speeches [1, p. 65].

These different types of projects have common emphasis on students' involvement, collaboration, and responsibility. In this aspect, project work is similar to the cooperative learning and task-oriented activities that are highly appreciated by educators interested in building communicative competence and purposeful language learning. But the project-based approach differs from the techniques mentioned; it requires a lot of students' time and effort to work on the given/chosen topic, both inside and outside the classroom, often in collaboration with speakers of the target language who are not normally involved in the educational process.

Effective project-based learning requires the teacher to assume a different role. The teacher's role is notdominant, but he/she acts as a guide, advisor, coordinator and 
facilitator. In implementing theproject method, the focal point of the learning process (as it was mentioned) moves from the teacher to the learners, to working alone or working in groups.

Among the advantages of the projectbasedmethod, we distinguish the following:

- increased motivation, since learners become personally involved in the project;

- all four language skills (reading, writing, listening and speaking) integration;

- terminal project as a resultand confirmation of work;

- authentic tasksthat facilitate creativity and language practice;

- interpersonal relations development through working as a group;

- the learner-centred approach, since content and methodology can be approved bythe learners and the teacher;

a break from routine lecture studying and the chance to do something different.

As any teaching technique, the project-based onehassuch weak points as noise made during the class (in case of working on the project at the lesson); projects are timeconsuming; students can use their mother tongue too much; weaker students are lost and not able to cope with the task; and finally, the assessment of projects is very difficult. However, the teacher's task is not only to create that kind of atmosphere where students are kept awayfrom difficulties, but also to get all of them engaged in working, having prepared the evaluation criteria beforehand. Having followed the instructions, the teacher can avoid those difficulties. Thus, we are sure that a rational and well-organised project causes no problems in its implementation.

As an example of project-based method realisation in teaching English at the university, we chose undergraduate philologists studying English as a second language for its implementation. Studyingthe course of Oral and Written Speech Practice the students have a possibility to be engaged in project work quite often. Let us consider the project adaption on the basis of the topic "House". For better understanding, we distinguished the following stages in working on projects:

Stage 1.

Choice of the project topic and announcing it with the aim of arousing interest and creating atmosphere contributing to speculation and investigation. Information on terms of the project, basic content and evaluation. The topic for research is "A Dream House" that must include not only one's own preferences but also the reasoned advantages and disadvantagesand specific vocabulary usage.

Stage 2.

Setting the aims of the project.

For the teacher:

Cognitive aims

- to help students learn about the types and the classifications of dwellings.
- to continue improving students' reading, writing, listening, speaking, vocabulary skills, and communicative competence.

\section{Emotional aims}

- to draw students' attentionto the problems connected with the development of the area;

- to instil respect of the collaborative efforts of people who lived in the specific houses and the specific geographical area.

\section{Psychomotor aims}

- to continue acquainting students with observation and research;

- to facilitate the development of curiosity and observation skills in students.

For students:

- to gather information on the given topic;

- to carry an analysis of types of houses;

- to make up a model of a perfect house;

- to consider all pros and cons of the chosen model;

- to take into consideration different personality types and their possible choice of a dream house.

Stage 3.

Designing the project activities: forming groups and assigning roles;making decisions concerning methodology, sources of information, activities, and places outside the classroom that students are supposed to visit (popular buildings in the city as the background for analysingarchitecture styles and types of houses). The better organisedand more analytical is the structuring of the activities, the easier and faster will be conducted the research.

Stage 4.

Students gather information, process and categorise it. If necessary, they may require intervals for information and feedback, in which students discuss issues related to cooperation among group members, problems of personal relations, and possible changes in the group composition.

Stages 5.

Displaying the projects in the forms of movies, graphics, schemes, essays, poems, multimedia presentations, interviews etc.Evaluation of the results referring to the assessment of the activities by participants and discussion of the results (whether the initial aims and goals have been achieved); implementation of the process, and final products. Evaluation implicates assessment of the experience at individual and group level, identification of errors and problems, as well as the appraisal of cognitive and experiential material gathered. Evaluation includes the estimationby others, as well asself-evaluation.

Project technology allowed students to integrate a variety of activities, making learning enthralling, more interesting and therefore, efficient. Students with different abilities became successful and felt they were needed in the project activities. Educational, social and communication skills were developed during the implementation of projects. At the preparatory stage, students practiced working with dictionaries, reference books, learnt to sort out their work. Project-based learning has changed students' attitude to the computer: computer has been trans- 
formed into a source of information and one of the ways of material presentation.

In contrast with traditional ways, the use of innovative forms of teaching makes a student a major participant of the educational process. Furthermore, the teacher should not solve only educational tasks, but also should create the conditions for students' independent research,

\section{ЛІТЕРАТУРА}

1. Гузеєв В. В. Метод проектів як окремий випадок інтегративної технології навчання / В'ячеслав Валер'янович Гузеєв // Директор школы. -1995. - №6. -C. 13-22.

2. Новікова Т. М. Проектні технології на уроках та у позакласній діяльності / Тетяна Миколаївна Новікова // Народное самообразование. - 2000. - №5 - C. 23-27.

\section{REFERENCES}

1. Huseiev, V. V. (1995). Metod proektiv yak okremyi vypadok intehratyvnoi tekhnolohii navchannia [Project-based method as a case of integrative teaching techology]. Direktor shkoly - School Headmaster, 6, 1322 [in Ukrainian].

2. Novikova, T. M. (2000). Proektni tekhnolohii na urokakh ta pozaklasnii diialnosti [Project-based technologies at the lessons and in extracurricular activities]. Narodnoye obrazovaniye - Public education, 7, 23-27 [in Ukrainian].

encouraging them to develop orientation skills and independent decision-making. The implementation of innovative methods in teaching is an essential prerequisite in solving educational problems. Constantly evolving system of information management in combination with technical support provides the highest quality of educational process.

3. Полат Е. С. Метод проектов на уроке английского языка / Евгения Семеновна Полат // Иностранные языки в школе.- 2000. - №3. - С. 3-9.

4. Coleman J. Project-based learning, transferable skills, information technology and video / John Coleman // Language Learning Journal. - 1992. - №5. - P. 35-37.

5. Haines S. Projects for the EFL Classroom. Resource Material for Teachers / Stanley Haines. - UK : Nelson. - 1992. - 149 p.

3. Polat, Ye. S. (2000). Metod proektov na uroke angliyskogo yazyka [Project-based method at English lessons]. Inostrannye yazyki v shkole - Foreign languages at school, 3, 3-9 [in Russian].

4. Coleman, J. A. (1992). Project-based learning, transferable skills, information technology and video. Language Learning Journal, 5, 35-37 [in English].

5. Haines, S. (1992). Projects for the EFL classroom. Resource material for teachers. UK: Nelson [in English].

Ольга Михайлівна Трубіцина, кандидат педагогічних наук, доцент, кафедра германської філології та методики викладання іноземних мов, Анна Анатолї̈вна Муймастер, студентка магістратури, факультет іноземних мов Південноукраїнський національний педагогічний університет імені К. Д. Уиинського, вул. Старопортофранківська, 34, м. Одеса, Україна

\section{МЕТОД ПРОЕКТІВ ЯК ІНТЕРАКТИВНИЙ МЕТОД НАВЧАННЯ АНГЛІЙСКОӤ МОВИ}

У статті розглянуто застосування методу проектів у викладанні англійської мови як іноземної у ВНЗ.Бурхливий розвиток науки та техніки вимагає застосування більш сучасних методів і підходів до навчання іноземних мов. Методами, які б повністю відповідали потребам суспільства, стають інтерактивні методи навчання, зокрема проектний, адже вони мають на меті підвищення усвідомленості та міцності отримуваного знання за рахунок сучасного та творчого підходу. Проаналізовано теоретичне підгрунтя та практична реалізація методу. Велика увага приділена походженню, головним концептам та перевагам методу проектів. Наразі метод проектів є одним із найсучасніших ефективних методик у викладанні англійської мови. Саме проектне навчання як один із інтерактивних методів найбільш сприяє розвитку пізнавальних здібностей учнів і студентів, готує їх до подальшої безперервної самоосвіти.Будь-яка проектна робота $\epsilon$, передусім, самостійною роботою, що здійснюєтьсяпід керівництвом вчителя чи викладача.Такий вид діяльності інтегрує індивідуальну та колективну навчально-пошукову активність, яка, в свою чергу, вимагає раціональної організації та успішного контролю. Головними ж цілями проектної самостійної роботи у ВНЗ є створення комфортних умов для розвитку особистості студента, адже проект вчить не тільки отримувати та відтворювати знання, а й творчо їх застосовувати; дати можливість студентові під час презентації проекту відчути, що він виступає як індивідуальність, здібна не лише оцінювати дійсність, а й проектувати зміни, необхідні для покращення рівня володіння англійською мовою.За характером проекти, що можуть бути застосовані у самостійній роботі студентів-першокурсників, поділяються на: дослідницькі (характеризуються продуманою структурою, визначенням цілей, обгрунтованою актуальністю предмета дослідження), творчі(велика увага приділяється оформленню результатів, формами якого 
можуть бути презентації, репортажі, альбоми, газети і т.д.), інформаційні (орієнтовані на збір інформації про певне явище чи подію з метою ознайомлення великої аудиторії з нею), практико зорієнтовані (мають чітко визначений результат діяльності учасників, який зорієнтований на соціальні інтереси чи потреби студентів, наприклад, права студентів, проект реконструкції навчального корпусу тощо).

Ключові слова: метод проектів, викладання, ВНЗ, іноземні мови, студенти.

\author{
Ольга Михайловна Трубицына, \\ кандидат педагогических наук, дочент, \\ кафедра германской филологии и методики преподавания иностранных языков, \\ Анна Анатольевна Муймастер, \\ студентка магистратуры, факультет иностранных языков, \\ Южноукраинский национальный педагогический университет имени К. Д. Уиинского, \\ ул. Старопортофранковская, 34, г. Одесса, Украина
}

МЕТОД ПРОЕКТОВ КАК ИНТЕРАКТИВНЫЙ МЕТОД ОБУЧЕНИЯ АНГЛИЙСКОМУ ЯЗЫКУ

В статье рассматривается использование метода проектов в преподавании английского языка как иностранного в ВУЗе. Бурное развитие науки и техники требует применения более современных методов и подходовкобучению иностранным языкам. Методами, которые полностью соответствовали бы нуждам общества, становятся интерактивные методы обучения, в числе которых и проектный, ведь они ориентированы на повышение осознанности и прочности получаемых знаний за счет современного творческого подхода. Дается анализ теоретической основы и практической реализации метода. Большое внимание уделяется происхождению, главным концептам и преимуществам метода проектов. На современном этапе метод проектов является одной из самых современных эффективных методик в преподавании английского языка. Именно проектное обучение как один из интерактивных методов способствует развитию познавательной активности учеников и студентов в полной мере, а также готовит обучаемых к дальнейшему непрерывному самообразованию. Любая проектная работа является, прежде всего, самостоятельной работой, осуществляемой под руководством учителя или преподавателя. Такой вид деятельности интегрирует индивидуальную и коллективную учебно-поисковую активность, которая, в свою очередь, требует рациональной организации и успешного контроля. Главными же целями проектной работы в ВУЗе являются создание комфортных условий для развития личности студента, так как проект учит не только получать и воспроизводить знания, а и творчески их применять; дать возможность студенту во время презентации проекта почувствовать, что он является индивидуальностью, способной не только оценивать действительность, но и проектировать изменения, необходимые для улучшения уровня владения английским языком. По своему характеру проекты, которые могут быть использованыдля самостоятельной работы студентов-первокурсников, бывают: исследовательские (характеризуются продуманной структурой, определением целей, обоснованной актуальностью предмета исследования), творческие (большое внимание уделяется оформлению результатов, формами которого могут быть презентации, репортажи, альбомы, газеты и т.д.), информационные (ориентированы на сбор информации об определенном явлении или событии с целью ознакомления большой аудитории с ней), практико-ориентированные (имеют четко определенный результат деятельности участников, ориентированный на социальные нужды или интересы студентов, например, права студентов, проект реконструкции учебного корпуса и т.д.).

Ключевые слова: метод проектов, преподавание, ВУЗ, иностранные языки, студенты.

Подано до редакиії 25.10.2016

Рецензент: д. пед. н., проф. Т. М. Яблонська 